\title{
Genetically Modified Soybean for Insect-Pests and Disease Control
}

\author{
Maria Fatima Grossi-de-Sa ${ }^{1,2}$, Patrícia B. Pelegrini ${ }^{1}$ and Rodrigo R. Fragoso ${ }^{3}$ \\ ${ }^{1}$ Laboratório de Interação Molecular Planta-Praga, Embrapa Recursos Genéticos e \\ Biotecnologia, Brasília - DF, \\ 2Universidade católica de Brasília, Brasília $-D F$, \\ ${ }^{3}$ Embrapa Cerrados, Planaltina $-D F$, \\ Brazil
}

\section{Introduction}

Since 1996, the cultivation of genetically modified (GM) crops around the world has increased more than 80-fold. In 2009, it was registered that a total area of 134 million hectares in 25 countries were used for biotech crops, which constituted a $7 \%$ increase from 2008. 14 million farmers, of whom $90 \%$ were small producers, grew GM cultivars in 25 countries during 2009. Nowadays, GM soybean, cotton and corn correspond to $99 \%$ of all GM cultivars planted worldwide (JAMES, 2009).

In the same year, with regard to the soybean crop, the planted area reached 90 million hectares worldwide, of which 69 million were GM. The world leaders of soybean production are the United States (33\%), Brazil (27\%) and Argentina (21\%), which are also leaders in the use of GM seeds. The eight following countries also cultivate GM soybean, seven of which are developing countries: Paraguay, South Africa, Uruguay, Bolivia, Mexico, Chile and Costa Rica (JAMES, 2009). Through this use, the GM seed market contributes to an amount of US\$ 10.5 billion annually to agriculture. Furthermore, GM soybean, along with corn and cotton, yielded US\$ 130 million in 2008 and US\$ 143 million in 2009 to the agribusiness sector, with a $10 \%$ increase projected for 2010. Each year, countries from the European Union import no less than 40 million tonnes of raw soy products, at a cost of more than U\$ 15 billion, mainly from the three biggest producers.

With respect to the agronomical traits used in GM crops, herbicide and insect resistance, or a combination of both traits, are the most utilised. Nevertheless, several other characteristics are being tested, such as increased nutritional quality, dry and cold tolerance, bacteria resistance, fungal and nematode resistances. Therefore, there is an expectation for future development of innovative molecular strategies in order to generate GM plants with novel features that promote reduction of costs and contamination risks for consumers, producers and the environment by decreasing the use of agrotoxic compounds.

Most of the soybean-planted area is comprised of herbicide-tolerant crops (62\%), distributed across 11 countries. Transgenic soybean with multiple combined traits corresponds to $21 \%$ of all biotech crops around the world (JAMES, 2009). During 2009/2010, a second generation of GM crops appeared in the market. RReady2Yield Soybean was cultivated by 15,000 
farmers distributed across 0.5 million hectares in the US and Canada, providing a higher production than traditional soybean crops.

Until January of 2009, there was no GM soybean that was resistant to insect-pests or pathogens being commercialised, although the need for this trait is extremely important. However, an insect-resistant event of GM soybean, developed in China, is in the commercial and regulatory pipeline in that country (STEIN e RODRIGUEZ-CEREZO, 2009 - Table 1). Today, there is only one commercial GM soybean event from Monsanto, which presents only herbicide-resistance as a trait. Four other GM soybean events are in the commercial pipeline (authorised but not yet commercialised), but all present herbicide resistance genes and demonstrate no resistance against pathogenic fungi, insect-pests or nematodes. In addition, three other soybean events resistant to herbicides are in the regulatory process required for worldwide marketing. Furthermore, two GM soybean events are already at late stages of development, although not yet in the regulatory process. While Monsanto is developing a soybean resistant to insect-pests, Syngenta is leading the development of a cultivar resistant to the cyst nematode (STEIN e RODRÍGUEZ-CEREZO, 2009 - Table 1).

\section{Major soybean pests and diseases}

Soybean plants originate from the South Asia region, where several microorganisms and insects evolved ecological interactions. All three major soybean-producing countries in the world are located on the American continent, where more than $50 \%$ of all soybeans are harvested. This geographic distribution facilitates the spread of insect-pests and diseases. Hence, soybean can be attacked by many different organisms, ranging from viruses to nematodes and insects. These pathogens and pests can cause damage in seeds, roots, leaves, stems and pods, and usually are tissue-specific. Here, we describe some of the most important diseases that attack soybeans, as well as the major pests and pathogens, mainly found in North and South America. A list of pathogens, the diseases they cause and the infected tissues are presented in Table 2 .

\subsection{Seedling diseases}

Diseases that affect soybean seeds occur before germination or after seedling establishment. The primary reason for this is the presence of wet and/or cool soil, which enables the growth of pathogenic fungi, such as Fusarium spp, Rhizoctonia solani, Phytophthora sojae and Phythium spp. In some locations, Macrophomina spp, Coletotrichum spp and Phomopsis spp can cause this type of damage in soybean seeds. Seedling diseases can decrease seed quality, due to variation in stands, which are formed by lesions on the cotyledons, soft young stems and primary leaves. Furthermore, these diseases can retard seedling growth, causing moderate to severe losses in crop yield and, in turn, a significant increase in the use of fertilisers and herbicides (MALVICK, 2007).

\subsection{Leaf pests and diseases}

There are several organisms that attack soybean leaves, including viruses, bacteria, fungi and insects. Among the diseases that have already been described, the most important are soybean rust, septoria brown spot, bacterial blight, bacterial pustule, downy mildew, cercospora leaf blight, frogeye leaf spot, powdery mildew, soybean mosaic virus and bean pod mottle virus. 


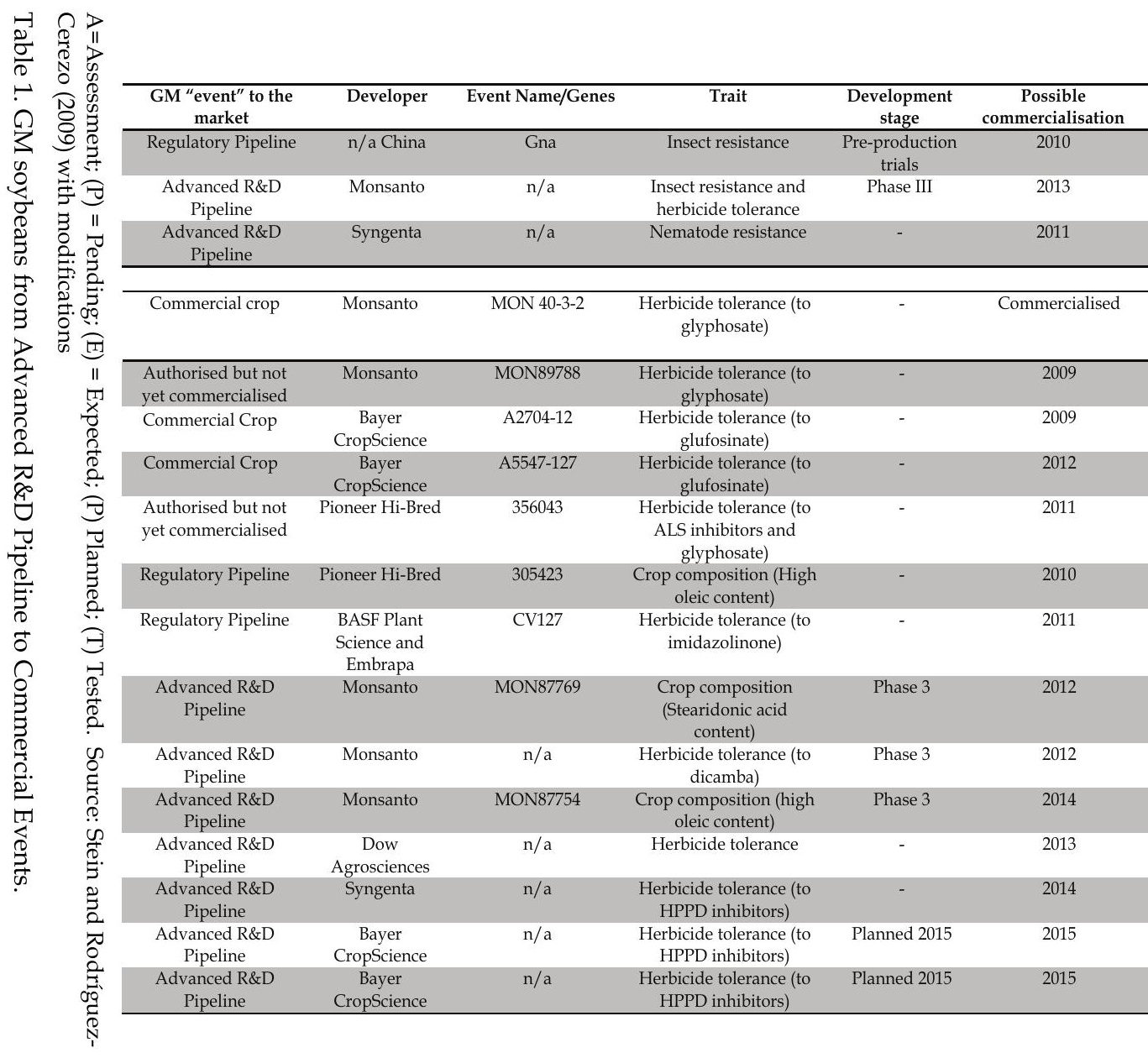




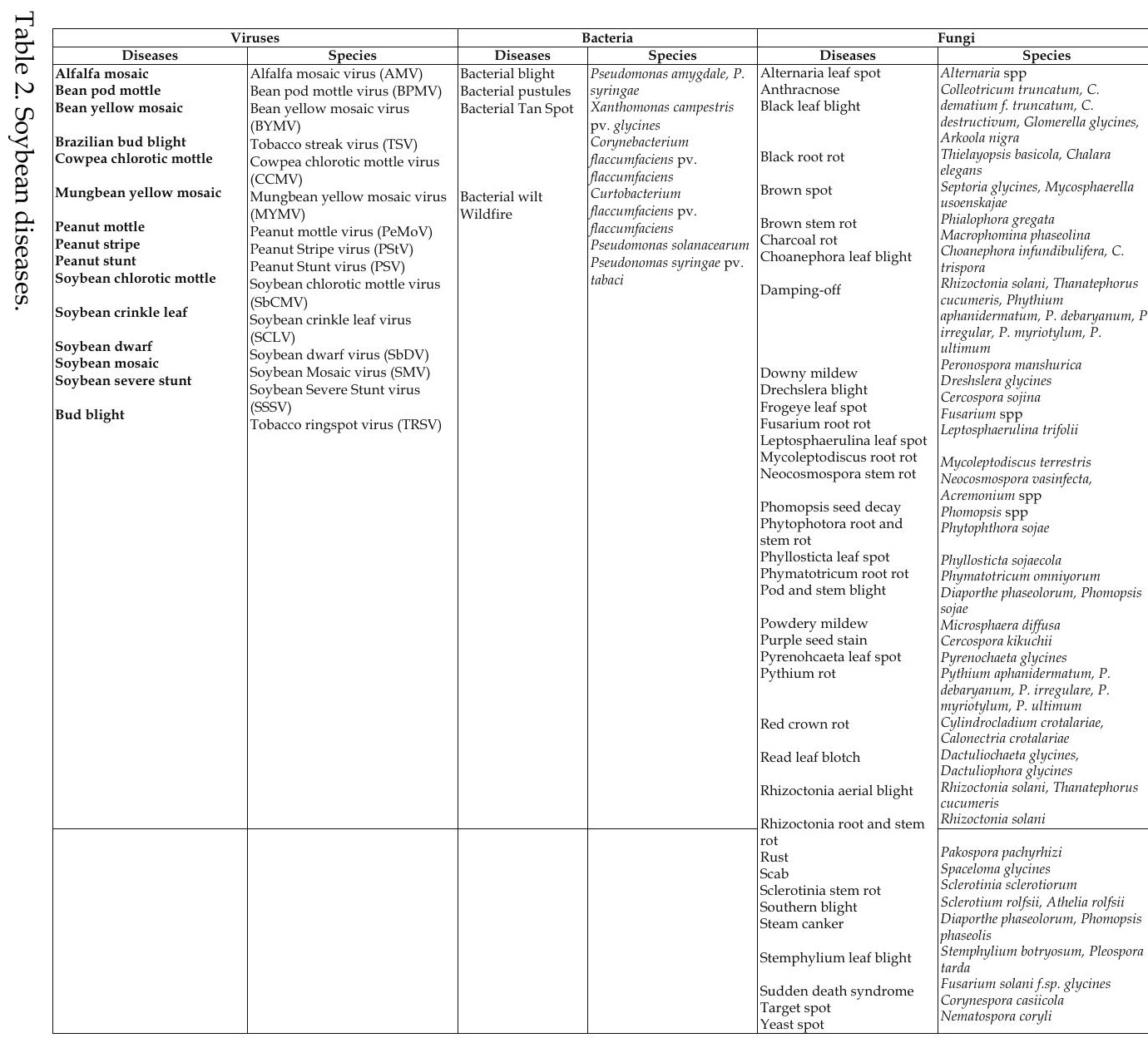


Fungi are the most common soybean pathogens, and include Phakopsora pachyrhizi and P. meibomiae, which are the main agents of soybean rust, a disease that causes up to $50 \%$ of all crop losses in the United States and Mexico. Moreover, Septoria glycines is the agent responsible for brown spot, a common disease characterised by defoliation following the formation of brown to red lesions, which affects not only trifoliolate leaves, but also primary leaves and cotyledons (DORRANCE et al., 2008; LUSTER et al., 2010). The fungal-like Peronospora manshurica is a worldwide pathogen that causes reduction of seed size and quality due to defoliation, leading to a disease called Downy Mildew (WYLLIE e WILLIAMS, 1965).

When soybean plants contaminated with Soybean Mosaic Virus (SMV) or the Bean pod mottle virus (BPMV), plants become susceptible to other pathogenic agents, especially fungi, which increase damage in the plant and treatment becomes more difficult. Virus diseases can affect seedlings, reducing their quality and germination growth. A decrease in yield is also observed, being less or greater depending on the gravity of the infection (GOLDBACH et al., 1995).

Bacterial infections are widespread diseases that occur mainly in the mid-to-upper and young leaves of the soybean plant. The bacterial blight and bacterial pustules are the most common diseases described thus far. While the first of these infections is characterised by the presence of blight lesions, the second shows light green spots on the surface of the leaves. Both diseases are very similar, rarely causing defoliation or yield loss (WRATHER et al., 2001; YANG, 1997).

Insect-pests are also significant predators of soybean leaves. Some Lepidoptera species, such as Anticarsia gemmantalis, known as the velvet caterpillar, cause damage in soybean plants, leading to defoliation (SWAN e PAPP, 1972). Spodoptera species also attack the leaves of soybean plants, although they are not tissue-specific and can spread to the pod as well as the entire plant in severe cases. Moreover, some Coleoptera insects have chosen soybean as one of their main target (MUSEUM, 2007). Hence, the Mexican bean beetle (Epilachna varivestis) and the Spotted cucumber beetle (Diabrotica speciosa) can cause defoliation, decreasing soybean quality and production (CAB/EPPO, 2003; CRANSHAW, 2004). Soybean insectpests are described in Table 3.

\subsection{Stem-and-Pod pests and diseases}

Fungi and insects are the major causes of stem and pod damage in soybean. Anthracnose is one of the most well-known fungal diseases, and it attacks soybean plants during wet and warm conditions. Colleotricum spp and Glomerella glycines may not cause significant yield loss, but they can reduce stand and seed quality (MACHADO e NETO, 2003). Some regions of the U.S. and Canada are commonly attacked by Sclerotinia stem rot (Sclerotinia sclerotiorum) every year (PURDY, 1979). In contrast to Anthracnose, these fungi appear during cool weather and resistant varieties of soybean are already being developed.

The insect-pests that target pods and stems in soybean cultivars are varied. Lepidoptera, Coleoptera and Hemiptera species contribute to a decrease in plant production and loss of quality (Table 3). In this way, Helicoverpa zea is an insect-pest widely distributed across North and South America that has been recently introduced to the Hawaiian Islands. This pest initially eats soybean leaves but can later attack pods, causing serious yield damage (HARDING, 1976). Furthermore, larvae of the soybean stem borer Dectes texanus texanus feed within young soybean plants, resulting in a small yield loss. However, severe stem damages from the inside of the plant can threaten an entire plantation (CAMPBELL e DUYN, 1977). 


\begin{tabular}{|c|c|c|c|}
\hline Order & $\begin{array}{c}\text { Soybean tissue } \\
\text { attacked }\end{array}$ & Popular Name & Scientific Name \\
\hline \multirow[t]{5}{*}{ Lepidoptera } & Leaf & $\begin{array}{c}\text { Green cloverworm } \\
\text { Soybean Looper } \\
\text { Velvetbean } \\
\text { Caterpilar } \\
\text { Saltmarsh } \\
\text { caterpillar } \\
\text { Yellowstriped } \\
\text { armyworm }\end{array}$ & $\begin{array}{c}\text { Plathypena scabra } \\
\text { Pseudoplusia includens } \\
\text { Anticarsia gemmatalis } \\
\text { Estigmene acrea } \\
\text { Spodoptera ornithogalli }\end{array}$ \\
\hline & $\begin{array}{c}\text { Lower leaves to the } \\
\text { whole plant }\end{array}$ & \multirow[t]{2}{*}{ Beet armyworm } & \multirow{2}{*}{$\begin{array}{c}\text { Spodoptera exigua } \\
\text { Spodoptera latifascia } \\
\text { Spodoptera } \\
\text { eridania }\end{array}$} \\
\hline & Leaf and Pod & & \\
\hline & Pod & $\begin{array}{l}\text { Corn Earworm } \\
\text { Silverspotted } \\
\text { skipper } \\
\end{array}$ & $\begin{array}{l}\text { Helicoverpa zea } \\
\text { Epargyreus clarus }\end{array}$ \\
\hline & Stem and Plantlet & & $\begin{array}{l}\text { Elasmopalpus lignosellus } \\
\text { Epinotia aporema }\end{array}$ \\
\hline \multirow[t]{3}{*}{ Coleoptera } & Leaf & $\begin{array}{c}\text { Mexican Bean } \\
\text { Beetle } \\
\text { Bean Leaf Beetle } \\
\text { Spotted Cucumber } \\
\text { Beetle } \\
\text { Blister Beetle } \\
\text { Japanese Beetle }\end{array}$ & $\begin{array}{c}\text { Epilachna varivestis } \\
\text { Cerotoma trifurcata } \\
\text { Diabrotica undecimpunctata howardi } \\
\text { Diabrotica speciosa } \\
\text { Epicauta pestifera, Epicauta } \\
\text { lemniscata } \\
\text { Aracanhtus mourei } \\
\text { Popillia japonica } \\
\text { Maecolaspis calcarifera } \\
\text { Megascelis sp. }\end{array}$ \\
\hline & Stem and Plantlet & $\begin{array}{l}\text { Soybean stem } \\
\text { borer } \\
\text { Grape colaspis } \\
\text { Leaf eating beetle }\end{array}$ & $\begin{array}{l}\text { Dectes texanus texanus } \\
\text { Colaspis brunnea } \\
\text { Sternechus subsignatus } \\
\text { Chalcodermus sp } \\
\text { Myochrous armatus } \\
\text { Blapstinus sp }\end{array}$ \\
\hline & Root & & $\begin{array}{c}\text { Phyllophaga cuyabana } \\
\text { Lyogenis suturalis }\end{array}$ \\
\hline \multirow[t]{3}{*}{ Hemiptera } & Pod & $\begin{array}{l}\text { Green Stink Bug } \\
\text { Brown Stink Bug }\end{array}$ & $\begin{array}{c}\text { Acrosternum hilare, Nezara viridula } \\
\text { Euschistus servus } \\
\text { Euchistus heros } \\
\text { Piezodorus guildinii } \\
\text { Maruca testulalis } \\
\text { Etiella zinckenella }\end{array}$ \\
\hline & Root & & $\begin{array}{c}\text { Scaptocoris castanea } \\
\text { Atarsocoris brachiariae } \\
\text { Dysmicoccus sp } \\
\text { Pseudococcus sp }\end{array}$ \\
\hline & Stem and Plantlet & $\begin{array}{l}\text { Threecornered } \\
\text { alfalfa hopper }\end{array}$ & $\begin{array}{c}\text { Spissistilus festinus } \\
\text { Dichelops melacanthus e Dichelops } \\
\text { furcatus } \\
\text { Thyanta perditor }\end{array}$ \\
\hline Orthoptera & Leaf & Grasshopper & Melanoplus spp \\
\hline
\end{tabular}

Table 3. Soybean Insect-pests 


\subsection{Root pests and diseases}

Although several fungi and insect species can damage soybean roots, nematodes are the most nocive and well-studied organisms that cause significant yield losses in this crop (Tables 2 and 3). Sedentary phytonematodes are divided into three classes: Globodera, Heterodera and Meloidogyne, and are the most nocive plant pathogens worldwide, causing losses of US\$ 125 billion annually in agriculture (CHITWOOD, 2003; SASSER, 1980). Parasitic nematodes are responsible for $12 \%-20 \%$ of all crop losses (KOENNING et al., 1999; SASSER e FRECKMAN, 1987). Worldwide losses caused by nematodes from the Meloidogyne genus can reach US\$ 16.5 billion per year in some cultivars (TRUDGILL e BLOK, 2001). Among these, Meloidogyne incognita is probably the most important nematode for agriculture, due to its worldwide distribution and the wide range of plants that it attacks (EHWAETI et al., 1999; TRUDGILL e BLOK, 2001). In addition, this species is responsible for $95 \%$ of nematode infestations around the world. By comparison, species from the genus Heterodera cause estimated annual losses of US\$ 430 million in the US and US\$ 95 million in Europe (MULLER, 1999; SASSER et al., 1983; WRATHER et al., 1997).

The soybean cyst nematode (Heterodera glycines) is a widespread pathogen that can be under the soil for years before it can be identified and the host eliminated. It usually causes nonevident symptoms, making diagnosis difficult. This nematode enters the plant root and starts to feed, not visible to the farmers. Consequently, soybean plant losses from this pathogen can reach $30 \%$ due to the late diagnosis and difficulties associated with pathogen control (ICHINOHE, 1988).

In addition, root-knot nematodes, represented by many species of Meloidogyne, are worldwide-distributed plant-parasites that feed on soybean roots, causing an average of $5 \%$ of crop loss around the world (SASSER e CARTER, 1985). They are most common in warm and moist soils, can easily be introduced into soybean roots and are difficult to control (EISENBACK e TRIANTAPHYLLOU, 1991; STIRLING et al., 1992).

In Brazil, the nematode Pratylenchus brachyurus can cause losses of $30-50 \%$ in some soybean fields. Their life cycle is very short, ranging from 3 to 4 weeks, which enables them to reproduce quickly and present many generations during the same cultivation period. Therefore, the control of $P$. brachyurus is very difficult, once that nematicides and culture rotation are inefficient strategies for the elimination of this plant parasite.

\section{Biotechnological strategies to circumvent pests and diseases}

\subsection{Bt soybean: a future tool on insect-pests control}

In nature, there are roughly 100 known bacterial species with potential for insect pathogenesis, but only a few have succeeded as bio-insecticides (ROWE e MARGARITIS, 2004). Among them, formulations based on Bacillus thuringiensis (Bt) have showed an effective activity against mosquito larvae and the insecticide activity of this bacteria is due to proteins produced during sporulation, which include a crystal complex (FEDERICI, 2005).

Insects from the Lepidoptera order are particularly susceptible to Cry1 toxins from $B$. thuringiensis (Bt toxins), which are highly toxic after ingestion. They are soluble and are processed by proteases presented in the insect midgut. The active toxins can interact with specific receptors at the midgut, leading to pore formation after toxin conformation change and, consequently, cell death (GILL et al., 1992; KNOWLES, 1994; RAJAMOHAN et al., 1998). Although this is the most commonly suggested method of action for Cry toxins, details about this mechanism, such as pos-binding effects and receptor specificities, are not yet clear (GOMEZ et al., 2002; ZHANG et al., 2005). 
In this way, genetic transformation of soybean to induce resistance to lepidopterans using the insertion of $\mathrm{Bt}$ toxins has been performed for over a decade. Hence, many techniques have been applied in order to successfully transfer Cry genes into soybean embryos. The bombardment method has provided stable transformed soybean plants (CHRISTOU, 1990; MCCABE e CHRISTOU, 1993). However, the use of Agrobacterium for transformation of cotyledonary nodes and the microprojectile bombardment of somatic embryos provided the growth of less fertile transformed plants (FINER e MCMULLEN, 1991; PARROTT et al., 1994; SATO et al., 1993; TOWNSEND e THOMAS, 1993). Nevertheless, years later, it was possible to produce a fertile transformed soybean containing a synthetic $B$. thuringiensis insecticidal crystal protein gene (Cry1Ac) through microprojectile bombardment. These plants showed resistance toward Helicoverpa zea, the soybean looper Pseudoplusia includes, the tobacco burworm (Heliothis virescens) and the velvetbean caterpillar (Anticarsia gemmatalis) (STEWART et al., 1996).

In order to increase plant resistance against insect-pests, pyramiding strategies were applied in soybean using a synthetic Bt toxin (Cry1Ac) with native plant resistance genes. Two QTLs from Japanese soybean lines, named 229-H and 229-M, have been described as showing antixenosis and antibiosis resistance towards lepidopteran insects (CREGAN et al., 1999). Hence, a GM soybean presenting a combination of 229-M from the strain PI 22948 and a synthetic cry $1 A c$ gene demonstrated resistance against $H$. zea, $P$. includens, A. gemmatalis and Elasmopalpus lignosellus (WALKER et al., 2000). Further studies utilised both QTLs, 229-H and 229-M, with the synthetic cry1Ac gene for production of transgenic soybean, which showed to be resistant against three lepidopteran insect-pests ( $H$. zea, $P$. includes and $H$. virescens) (WALKER et al., 2004). Later, new reports described the production of a GM soybean containing a third QTL, named QTL-G, along with the cry1Ac resistance gene. It was showed that QTL-M presented the largest effect on P. includens and H. zea resistance. QTL-G worked better against $H$. zea larvae (RECTOR et al., 2000; ZHU et al., 2008), while QTL-H was not as effective when compared to the other two resistance genes (WALKER et al., 2004; ZHU et al., 2008). Therefore, the addition of another QTL, in order to increase insect resistance, represents an interesting strategy for biological control in soybean cultivars (ZHU et al., 2008).

Recently, transgenic lines of soybean expressing the B. thuringiensis toxin Cry1Ac were tested in the field for their potential resistance against lepidopteran pests. It was demonstrated that $\mathrm{Bt}$ toxins could also be used in soybean as a resistance methodology aimed towards $A$. gemmatalis, P. includens, and Hypena scabra (MCPHERSON e MACRAE, 2009).

\subsection{Digestive enzyme inhibitors}

The occurrence of proteinase inhibitors (PIs) as defence-related proteins and their role on plant protection are well described in the literature. Since 1947, it has been observed that PIs from soybean were able to inhibit the growth of insect-pests larvae, including the coleoptera Tribolium confusum (HAQ et al., 2004; LYSON, 2002; MICKEL e STANDISH, 1947). Later, in vitro and in vivo bioassays demonstrated that protease inhibitors were also active against other insect species, such as Anagasta kuehniella, Hypera postica and Anthonomus grandis (FRANCO et al., 2003; MACEDO et al., 2003; WILHITE et al., 2000). Hence, as there is no evidence that proteinase inhibitors have toxic or deleterious effects on mammals, they constitute a significant alternative for the development of transgenic crops resistant to insect-pests and nematodes.

Soybean cultivars are predated by several insect species, requiring the application of different insecticide compounds in agriculture. Proteinase inhibitors, such as AKTI (Albizzia 
kalkira proteinase inhibitor), could, therefore, be a promising choice, as it has been shown to reduce the activity of the beet armyworm S. exigua by $57 \%$ (ZHOU et al., 2008).

Approaches for the development of genetically engineered soybean lines, which express insecticidal molecules, are also being widely studied. Transgenic tobacco expressing a cowpea trypsin inhibitor (CPTI) showed activity against Heliothis virescens larvae (GATEHOUSE et al., 1993), as well as species from Diabrotica spp and Spodoptera spp (HILDER et al., 1987). However, it was shown that in Nicotiana tabacum transgenic plants expressing the barley trypsin inhibitor BTI-CMe, although larvae of Spodoptera exigua were susceptible to the proteinase inhibitor, they were able to produce alternative proteins that could maintain survivance of the insect-pest (LARA et al., 2000). This report demonstrated the adaptation development of S. exigua over genetically modified tobacco cultures.

The inhibition of nematode digestive enzymes is one type of anti-feeding strategy, exemplified by plant transformation with genes encoding proteinase inhibitors (ATKINSON et al., 2001; LILLEY et al., 1999a; LILLEY et al., 1999b). To this end, there are reports that describe the characterisation of proteinase activities in crude protein extracts of plant-parasitic nematodes (LILLEY et al., 1996; MICHAUD et al., 1996) or the isolation of their proteinase genes (FRAGOSO et al., 2005; FRAGOSO et al., 2009; LILLEY et al., 1997; NEVEU et al., 2003; URWIN et al., 1997a). For example, the production of a genetically modified Arabidopsis thaliana with a gene encoding the modified proteinase inhibitor from rice, cystatin Oc- 1 delta D86, was able to inhibit growth of Heterodera schachtii and Meloidogyne incognita females, blocking egg production and pest proliferation. Other reports showed the potential application of anti-feeding strategies based on plant transformation to express proteinase inhibitors (ATKINSON et al., 2001; URWIN et al., 1997b; URWIN et al., 1998), proteinase gene silencing by RNAi (URWIN et al., 2002), in vitro inhibition of cysteine proteinase activity using the cognate pro-region of nematode cysteine proteinase (SILVA et al., 2004) and the transformation of soybean roots to express the propeptide (MARRA et al., 2009).

\subsection{Defensins: small tools against insect resistance}

Defensins are antimicrobial peptides varying from 45-54 amino acid residues stabilised by 34 disulfide bridges, which are isolated from different sources, such as plants, mammals, insects and crustaceous (THOMMA et al., 2002). They have been described as important tools for the control of pathogenic fungi, especially Rhizoctonia solani and Fusarium species, which are important organisms that causes damage in soybean cultivars (OLLI e KIRTI, 2006; WANG e NG, 2007). Therefore, the study of defensins may lead to the development of future transgenic plants encoding peptides toxic to these phytopathogenic fungi.

It was previously demonstrated that a recombinant defensin from mungbean (rVrD1) was able to inhibit the growth of $R$. solani and F. oxysporum (CHEN, 2004). The same fungi also had their activity inhibited by another defensin-like peptide, called coccinin, isolated from the seeds of large scarlet runner beans (Phaseolus coccineus) (Ngai et al., 2004). Furthermore, Tfgd1, a recombinant defensin from the legume Trigonella foenum-graecum, demonstrated similar features, inhibiting the growth of $R$. solani at a low concentration (OLLI e KIRTI, 2006). In addition, $F$. oxysporum growth was strongly affected by the recombinant Vitis vinifera antimicrobial peptide (Vv-AMP1), as well as by the peptide from the flowers of Nicotiana alata, NaD1 (BEER e VIVIER, 2008; WEERDEN e ANDERSON, 2008). Psd1, a defensin isolated from pea seeds, was also able to decrease growth of the phytopathogen $F$. solani by interacting with the fungus membrane, leading to cell death (MEDEIROS et al., 2010). Many other defensins have been characterised as having antifungal activities, and these can be observed in Table 2 . 
Studies on the expression of defensins in transgenic model plants are confirming the activity of foreign peptides as an important tool against soybean pathogenic fungi. Hence, using Arabidopsis thaliana as an expression system, defensins PDF1.1 and PDF1.3 were produced, purified and analysed against several fungi species, showing activity against two soybean pathogens, F. graminearum and F. oxysporum (SELS et al., 2007).

\subsection{Using spider and scorpion venom toxins as novel insecticidal mediators}

Scorpion and spider venoms are being studied for their several physiological and pharmacological effects against pests and pathogens (ROCHAT et al., 1979; ZLOTKIN et al., 1991).

Scorpion toxins seem to have specificity to some insects that cause economic crop losses around the world, including soybean loss. Therefore, such toxins are being evaluated for use in future development of recombinant biopesticides as an alternative strategy to control insect-pests. Several insect-related toxins have been identified from scorpions, isolated from diverse geographical locations (BECERRIL et al., 1995; CREST et al., 1992; NAKAGAWA et al., 1997; ZLOTKIN et al., 1991). In this manner, toxins purified from the venom of the spider Plectrurys tristis demonstrated insecticidal activity against $H$. virescens, an insect-pest of soybean cultivars (QUISTAD and SKINNER, 1994). Moreover, a toxin identified from the venom of Mesobuthus tumulus, called ButaIT, showed high antagonistic activity towards the insect $H$. virenscens (WUDAYAGIRI et al., 2001).

The interest in developing insecticidal compounds for field application in order to reduce the use of chemical agrotoxics and decrease insect resistance has led to new biotechnologybased approaches. Although not yet used in soybean plants, the insertion of a gene encoding toxin into the genome of a plant or baculovirus is a potential alternative (KHAN et al., 2006; LIMA et al., 2007; STEWART et al., 1991). The fusion of a toxin to the N-terminal of insect lectins has also given successful results. Lectins can act as carrier proteins and direct the fused toxins to the insect haemolymph, causing death (PHAM TRUNG et al., 2006).

\subsection{Using gene silencing for nematode control}

One of the techniques utilised in soybean biotechnological products is the genetic transformation of cultivars expressing double strand RNAs (dsRNA) in order to drive gene silencing in nematodes. The mechanism of pos-transcription gene silencing using dsRNA is known as RNA-mediated interfering (RNAi), or gene silencing (BOSHER e LABOUESSE, 2000; HUNTER, 2000; KUWABARA e COULSON, 2000; SHARP, 1999). Gene silencing can be either partial - called knckdown - or total - denominated knockout.

Briefly, the RNAi mechanism uses DICER complexes (dsRNA-specific RNase III-type endonuclease), which recognise and digest the dsRNA into siRNAs (small interfering RNAs) that ranges from 21-26 base pairs. These siRNAs flow through four possible pathways. First, siRNAs bind to the RISC complex (RNA-induced silencing complex) to search for and destroy complementary mRNA. Second, siRNAs bind to the RdRp complex (RNA-dependent RNA polymerase), priming mRNAa to synthesise new dsRNAs, and potentialising the entire RNAi process. Third, siRNAs bind to the membrane protein complex SID (systemic RNAi), which spreads out siRNAs to neighbourhood cells and, probably, to all cells, generating a systemic response of gene silencing. Fourth, siRNAs bind to the RITS complex (RNA-induced transcriptional silencing), which drives heterochromatin condensation of homologous regions, directing gene promoter turn-off and, consequently, pre-transcriptional gene silencing. 
Researchers have applied RNAi technique in order to evaluate the effect of RNAi on nematode development. This method was already widely used in the free-living nematode Caenorhabditis elegans, and its effect is normally gene-specific, systemic, lasting, or even hereditary (ALDER et al., 2003; BARGMANN, 2001; BARSTEAD, 2001).

Several reports use the methodology of in vitro dsRNA production and administration of nematodes by incubation (soaking), followed by plant infection for the determination of parasitism, such as the levels of reproduction and survival. Some silenced target genes showed high potential for use in parasitism control, such as: (i) proteinase genes in cyst nematodes Heterodera glycines and Globodera pallida (URWIN et al., 2002), and root-knot nematode $M$. incognita (SHINGLES et al., 2007); (ii) chitin synthase in M. artiellia (FANELLI et al., 2005); (iii) aminopeptidase in H. glycines (LILLEY et al., 2005); (iv) cellulases in G. rostochiensis (CHEN et al., 2005) and H. glycines (BAKHETIA et al., 2007); (v) amphideal secretion protein in G. rostochiensis (CHEN et al., 2005); (vi) FMRF-like peptides in G. pallida (KIMBER et al., 2007); (vii) pectate lyase, corismato mutase and secretion peptide SYV46 in H. glycines (BAKHETIA et al., 2007); and (viii) double oxidase in M. incognita (BAKHETIA et al., 2005).

Another strategy commonly applied is the use of transformed plants that express nematode target-gene dsRNAs and their evaluation in the presence of nematode infection. In this way, some plants showed partial-to-complete nematode resistance, as observed for the peptide 16D10 dsRNA expressed in Arabisopsis thaliana increasing resistance against $M$. incognita, $M$. javanica, M. arenaria and M. hapla (HUANG et al., 2006). Moreover, the major sperm protein dsRNA showed increase of soybean resistance towards H. glycines in soybean (STEEVES et al., 2006). Reports also describe the successful use of this technique, such as in the silencing of $M$. incognita genes that encode a splicing factor and an integrase. After nematodes were fed with RNAi transformed tobacco roots, they showed smaller and fewer healthy females when compared to those that were fed the control plants (YADAV et al., 2006). Later, it was demonstrated that the exposure of nematodes to RNAi fragments increased their susceptibility to RNAi delivery, confirming the importance of gene silencing techniques as biotechnological tools to improve plant resistance to pathogenic nematodes (LILLEY et al., 2007). Earlier studies also reported that the silencing of a gene encoding cathepsin L-cysteine (mi-cpl-1) from $M$. incognita was able to decrease the number of fertile females. In this case, the production of eggs was reduced to $40 \%$ using only a small fragment of the respective gene ( $800 \mathrm{bp}$ ) (SHINGLES et al., 2007). Moreover, studies of the transcription factor of M. javanica in tobacco plants produced satisfactory results, showing that the RNAi technique is an excellent strategy to study plant resistance to phytopathogenic nematodes (FAIRBAIRN et al., 2007).

Recently, it was reported that the use of four different RNAi gene-silencing constructs was able to decrease cyst nematodes in transformed soybean roots (KLINK et al., 2005; KLINK et al., 2009). Furthermore, another study showed that silencing of a tyrosine phosphatise gene and a mitochondrial stress-70 protein precursor from $M$. incognita provided the reduction of gall formation in transformed soybean. It also revealed that nematode development was affected by RNAi constructs (IBRAHIM et al., 2010).

Target-specific RNAi of the $H$. schachti gene Hg4F01, a related species of $H$. glycines, expressing an annexin-like protein was also studied in order to identify its function on nematode resistance. H. schachti was used in this work because of its effect on Arabidopsis thaliana, which could not be performed with $H$. glycines. Hence, using plant-host derived RNAi and the Arabidopsis-cyst nematode system, it was demonstrated that the annexin-like protein had a significant effect on plant-nematode interactions. In addition, it was concluded 
that the expressed protein, which is also produced in Arabidopsis, may mimic plant annexin function (PATEL et al., 2010).

\section{Directing transgene expression to attacked tissues}

\subsection{Promoter isolation and characterisation}

Once the Cauliflower Mosaic Virus (CaMV) 35S promoter was isolated and characterised (ODELL et al., 1985), it became the major general-purpose and most widely-used promoter in GM plants (HERNANDEZ-GARCIA et al., 2009). CaMV $35 S$ is the promoter of choice in more than $80 \%$ of GM plants (HULL et al., 2002), because it drives constitutive high levels of transgene expression (VENTER, 2007).

Despite the great success of the $35 \mathrm{~S}$ promoter, there is a scientific interest in discovering new promoters with differentiated and specialised functions. Moreover, the stability and expression pattern of foreign genes driven by the $35 \mathrm{~S}$ promoter has been tested and questioned (BAKHSH et al., 2009; WESSEL et al., 2001). Therefore, the discovery of plant promoters was essential to drive predictable temporal and tissue-specific expression patterns and high levels of protein production (LU et al., 2008). When evaluating transgenic strategies for nematode control, although widely used, the $35 \mathrm{~S}$ promoter has certain limitations, such as its poor performance in monocots, and its suppression when feeding nematodes (URWIN et al., 1997c).

Plant promoters used in biotechnology are divided into three categories based on gene expression pattern: constitutive (almost everywhere, every time); spatiotemporal (tissuespecific and/or stage-specific); and inducible (regulated by some specific signal) (POTENZA et al., 2004). Inducible promoters can fit into three categories: endogenous-signal responsive (plant hormones); external, physical-stimuli responsive (abiotic and biotic stresses); and external, chemical-stimuli responsive (PEREMARTI et al., 2010).

Plants have evolved defence mechanisms to combat pests and pathogens. Some defence mechanisms are innate, others are only active when and where there is an attack. These mechanisms, therefore, are dependent on biotic-interaction detection, functionality of signalling pathways, defence-gene expression, cellular- and tissue-defence activation. The expression of defence genes is driven by chemical-inducible promoters, when elicitors produced by pests and pathogens are recognised by plants (PEREMARTI et al., 2010). Similarly, pest wounding generates physical signals which direct expression of defence genes. Both elicitor-inducible and wound-inducible promoters are relatively well-conserved across taxonomic groups, implying wide plant species spectra in transgenic strategies (PEREMARTI et al., 2010).

Plant cellular response to biotic stress - initiated by biochemical signalling cascades that detect pest injury or pathogen invasion - can be carried out by activation and/or inhibition of transcription factors (trans-elements). In turn, they bind to specific DNA sequences (ciselements) to regulate gene expression. In this way, resistance mechanisms are activated only, or mainly, when and where there is an attack, and achieve a lethal dose. Besides identifying genes to control pests and diseases, the use of such biotic-stress induced promoters could ensure transgene expression primarily in affected tissues, specific to a specific targeted pest or pathogen.

Root-knot and cyst nematodes induce plant cell differentiation to generate nematode feeding sites, giant cells and syncytia, respectively, which act as nutrient sinks. Such cellular modification, coordinated by a complex gene-regulation network, is under examination in 
several studies in order to find key transcription factors. Some nematode-induced promoters could represent excellent vectors for the administration of lethal doses to nematode feeding sites in infected roots.

Hence, a soybean heat shock protein 90-like promoter (GmHSP90L) and a soybean polyubiquitin promoter (Gmubi) have shown higher expression levels of the gfp gene than the cauliflower mosaic virus 35S promoter (CaMV35S), when transformed in cotyledons of germinating lima bean (Phaseolus lunatus) seeds (CHIERA, 2007). An intronic region (Gumpri) from the Gmubi promoter seems to be essential for increasing gene expression levels. It was demonstrated that the activity of Gmubi promoter was two times higher than CaMV35S promoter when the intron was removed, compared to a five times higher when the intronic region was present. Similar results were also obtained for ubiquitin promoters from other sources. The ubiquitin promoter from rice showed no activity when the intronic region was removed (WANG e OARD, 2003). Also, The expression of the same promoter in tobacco was not only reduced when the intron was not present, but the tissue-specific expression was altered (PLESSE et al., 2001). Moreover, the GmHSP90L promoter showed stronger expression levels than CaMV35S, but the expression level decreased after promoter truncation, revealing that this region might be related to GmHSP90L promoter regulatory elements (CHIERA, 2007). Detailed studies of gene expression at nematode feeding sites have been performed by several research groups, and some nematode-induced promoters have been identified and characterised. The TobRB7 gene (enconding a water channel protein - OPPERMAN et al., 1994), the Hahsp17.7G4 gene - which encodes a heat shock protein (ESCOBAR et al., 2003) and the E2 gene (enconding the ubiquitin conjugation factor 2 - BIRD, 1996), are al highly expressed in the giant cells of $M$. incognita.

Ubiquitination plays important roles, such as on mediating lipidation, protein activity regulation, protein-protein interaction control, subcellular localisation (MUKHOPADHYAY e RIEZMAN, 2007), transcription control through histone ubiquitination, translation control, DNA repair, regulation of endocytosis and protein trafficking (MURATANI e TANSEY, 2003). Indeed, ubiquitination regulates various aspects of plant life, including disease resistance (ZENG et al., 2006), hormone signalling (ITOH et al., 2003), many developmental processes and cell cycle control (MOON et al., 2004). Thus, the E2 enzyme, a member of the Leubc4 family, has a major role in cellular metabolism and giant cell formation. Because of this, its promoter region was suggested for promoter characterization and use as biotechnological tool for root-nematode control (BIRD, 1996). Therefore, the soybean E2 gene promoter, named UceS8.3, was isolated and characterised for further use in soybean genetic transformation (GROSSI-DE-SA et al., 2008). In the same way, the soybean polyubiquitin gene promoter was isolated and characterised (HERNANDEZ-GARCIA et al., 2009).

Functional genomic studies have been applied to study plant-nematode interactions, in order to identify genes that were up-regulated and down-regulated at nematode feeding sites. The use of microarray hybridisation, serial analysis of gene expression (SAGE) and proteomic methodologies (FRANCO et al., 2010; MEHTA et al., 2008) achieved gene expression analyses at genomic scale, while quantitative real time PCR, in situ hybridisation and Laser Capture Microdissection techniques provided more accuracy in comparing differences in promoter expression.

The use of novel promoters for gene expression control can be widely used in genetically modified soybean in order to direct the foreign gene to a specific tissue attacked by a certain pest or pathogen. In this way, some promoters identified in soybean have been studied in model plants and compared with other existing promoters from other sources. 
Hence Khan and colleagues (2004) made comparisons of 1,300 cDNAs from soybean infested with H. glycines at 2 dpi (Table 4). Klink and colleagues (2005) used laser capture microdissection to collect syncytia of soybean under 8-dpi infestation with H. glycines. A total of $800 \mathrm{cDNAs}$ were sequenced, assembled as 174 consensus sequences, where 6 were up-regulated, 1 was down-regulated and 5 were both activated or inhibited, as confirmed by qRT-PCR. Later, Aklharouf and colleagues (2006), using microarray chips with more than 6,000 cDNA spots, detected hundreds of differentially expressed genes at from 6 hours (hpi) to 8 days post-infection (dpi). ITHAL and colleagues (2007a) simultaneously compared infested and non-infested soybean roots and different development stages of $H$. glycines at 2, 5 and 10 dpi. The microarray analysis of 35,611 soybean genes and 7,431 nematode genes detected 429 plant genes and 1,850 nematode genes with differential gene expression. ITHAL and colleagues (2007b) made microarray hybridisations to study syncytia development from 0 to $10 \mathrm{dpi}$. Using chips with 35,611 soybean genes, they observed 1,765 genes with changes in expression pattern until $2 \mathrm{dpi}$, when 1,116 genes were up-regulated, while 649 genes were down-regulated.

\section{Perspectives on GM soybean for insect-pests and diseases control}

The glyphosate-tolerant GM soybean alone corresponds to $52 \%$ of all biotech crops planted world area. Indeed, considering soybean, herbicide tolerance has still been the major aimed trait, with around ten novel varieties showing tolerance to different chemical compounds in their final steps of $\mathrm{R} \& \mathrm{D}$ pipeline to commercial events.

However, there is an obvious need and seed market demand for insect-pests and plantpathogens resistance traits. In a very near future, the first GM soybean resistant to insectpests and nematode will be available as single traits or together with herbicide tolerance (stacked traits).

In that way, several biotechnological strategies and their candidate genes have been tested in order to induce resistance to various pests and diseases, including the tissue overexpression of genes driven by specific plant promoters. Hence, it is expected to observe, in a near future, the production of soybean and its processed products with less or none agrotoxic residues or micotoxins from opportunistic fungi, as it has been already seen by the GM maize containing a Bt toxin. Consequently, it is also expected that further GM soybean traits enable a relevant decrease of costs with chemical pesticides, the enhancement of soybean quality and crop production, as well as the maintenance of a non-poluted and biodiverse environment.

Recenlty, the Academy of Science from the Vatican announced their support on the production of transgenic plants. The report was published in an International Scientific Journal and signed by 40 specialists - including 7 from the Vatican itself. Among other things, the report described the need for development of new agricultural technologies in order to decrease malnutrition and starvation that surrounds 1 billion people of the world (Potrykus et al., 2010). This announcement brought new perspectives for biotechnology, once that now religion and science are walking together for the improvement of food supply and the development of new techniques into plant transformation. Therefore, it is expected that, in future, more advanced strategies provide the cultivation of several transgenic crops with diverse resistances towards pests, pathogens and environment conditions, with the approval for consumption not only from Inspection Organizations, but from the entire society. 


\section{Biologic process or predict gene function (Protein)}

Time pos infestation

(analysis technique)
Reference

$\Delta$ Defence

$\Delta$ Stress response (peroxidase; SAM22)

$\Delta$ Carbohydrate metabolism

A Cellular signalling

A Unknown

$\Delta$ Defence (SRG2)

$\Delta$ Water channel (GmPIP2,2)

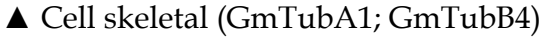

$\Delta$ DNA binding (MYB-related protein)

$\boldsymbol{\nabla}$ Protein catabolism (ubiquitin)

$\Delta$ Defence

$\Delta$ Wounding response

A Transcription factor (WRKY)

$\Delta$ DNA duplication

$\Delta$ RNA transcription

A Protein translation

$\Delta$ Unknown

$\Delta$ Defence

A Stress response (peroxidase)

$\Delta$ Primary and secondary metabolism

\author{
2 dpi \\ (Microarray) \\ (KHAN et al., 2004) \\ (KLINK et al., 2005)
}

$\Delta \boldsymbol{\nabla}$ Cell wall modification

$\Delta$ Plant development

$\Delta$ Cellular signalling

A Transcription factor (WRKY; bZIP;

ERF; MYB)

$\Delta$ Disease related

$\Delta$ Primary and secondary metabolism

2, 5 and $10 \mathrm{dpi})$

(ITHAL et al., 2007b)

2, 5 and $10 \mathrm{dpi}$

(ITHAL et al., 2007a)

1, 2, 4, 6 and 8 dpi

(Microarray)

(EST library)

(Microarray)

$\Delta \boldsymbol{\nabla}$ Cell wall modification

$\boldsymbol{\Delta}$ Lignin and suberin biosynthesis

$\Delta \boldsymbol{\nabla}$ Transporter of sugar, metal ion

and amino acid
$\Delta \boldsymbol{\nabla}$ Auxin related
$\Delta \boldsymbol{\nabla}$ Ethylene related
$\boldsymbol{\nabla}$ Cytokinin related
$\boldsymbol{\nabla}$ Gibberellin related
$\boldsymbol{\nabla}$ Jasmonic acid biosynthesis
$\Delta$ Development related (PHAP2A)
$\nabla$ Water channel (Rb7)

Differential expression of individual genes, relative to non-infested plants, at different times was associated to predicted gene function and biologic process. The arrows represent predicted biological process activation $(\mathbf{\Lambda})$, inhibition $(\boldsymbol{\nabla})$ or undetermined $(\boldsymbol{\Lambda} \nabla)$, considering the results of individual upor down-regulated genes.

Table 4. Biologic process modification during infestation of G. max plants by H. glycines. 


\section{References}

ALDER, M. N.; DAMES, S.; GAUDET, J.; MANGO, S. E. Gene silencing in Caenorhabditis elegans by transitive RNA interference. Rna, v. 9, n. 1, 25-32, 2003.

ALKHAROUF, N. W.; KLINK, V. P.; CHOUIKHA, I. B.; BEARD, H. S.; MACDONALD, M. H.; MEYER, S.; KNAP, H. T.; KHAN, R.; MATTHEWS, B. F. Timecourse microarray analyses reveal global changes in gene expression of susceptible Glycine max (soybean) roots during infection by Heterodera glycines (soybean cyst nematode). Planta, v. 224, n. 4, 838-852, 2006.

ATKINSON, H. J.; GREEN, J.; COWGILL, S.; LEVESLEY, A. The case for genetically modified crops with a poverty focus. Trends Biotechnol, v. 19, n. 3, 91-6, 2001.

BAKHETIA, M.; CHARLTON, W.; ATKINSON, H. J.; MCPHERSON, M. J. RNA interference of dual oxidase in the plant nematode Meloidogyne incognita. Molecular Plant-Microbe Interaction, v. 18, n. 10, 1099-1106, 2005.

BAKHETIA, M.; URWIN, P. E.; ATKINSON, H. J. qPCR analysis and RNAi define pharyngeal gland cell-expressed genes of Heterodera glycines required for initial interactions with the host. MOLECULAR PLANT-MICROBE INTERACTIONS, v. 20, n. 3, 2007.

BAKHSH, A.; RAO, A. Q.; SHAHID, A. A.; HUSNAIN, T.; RIAZUDDIN, S. CaMV 35S is a developmental promoter being temporal and spatial in expression pattern of insecticidal genes (Cry1ac \& Cry2a) in cotton. Research Journal of Cell and Molecular Biology, v. 3, n. 1, 56-62, 2009.

BARGMANN, C. I. High-throughput reverse genetics: RNAi screens in Caenorhabditis elegans. Genome Biol, v. 2, n. 2, REVIEWS1005, 2001.

BARSTEAD, R. Genome-wide RNAi. Curr Opin Chem Biol, v. 5, n. 1, 63-6, 2001.

BECERRIL, B.; CORONA, M.; GARCIA, C.; BOLIVAR, F.; POSSANI, L. D. Cloning of genes encoding scorpion toxins: An interpretive review. Journal of Toxicology Toxin Review, v. 14, n., 339-357, 1995.

BEER, A. D.; VIVIER, M. A. Vv-AMP1, a ripening induced peptide from Vitis vinifera shows strong antifungal activity. BMC Plant Biology, v. 8, n., 75, 2008.

BIRD, D. Manipulation of host gene expression by root-knot nematodes. Journal of Parasitology, v. 82, n., 881-888, 1996.

BOSHER, J. M.; LABOUESSE, M. RNA interference: genetic wand and genetic watchdog. Nat Cell Biol, v. 2, n. 2, E31-6, 2000.

CAB/EPPO. Distribution Maps of Plant Pests. Washington (GB), CAB International, 2003.

CAMPBELL, W. V.; DUYN, J. W. Cultural and chemical control of Dectes texanus on soybeans. Journal of Economic Entomology, v. 70, n., 256-258, 1977.

CHEN, Q.; REHMAN, S.; SMANT, G.; JONES, J. T. Functional analysis of pathogenicity proteins of the potato cyst nematode Globodera rostochiensis using RNAi. Molecular Plant-Microbe Interaction, v. 18, n. 7, 621-625, 2005.

CHEN, S. Y. Feedback-insensitive anthranilate synthase gene as a novel selectable marker for soybean transformation. Sheng Wu Gong Cheng Xue Bao, v. 20, n. 5, 646-51, 2004.

CHIERA, J. M., BOUCHARD, R. A., LING, P. P., FINER, J. J. Isolation of two highly active soybean (Glycine max (L.) Merr.) promoters and their characterization using a new automated collection and analysis system. Plant Cell Rep, v. 26, n., 1501-1509, 2007. 
CHITWOOD, D. J. Research on plant-parasitic nematode biology conducted by the United States Department of Agriculture-Agricultural Research Service. Pest Management Science, v. 59, n. 6-7, 748-753, 2003.

CHRISTOU, P. Soybean transformation by electric discharge particle acceleration. Physiology Plan, v. 79, n., 210-212, 1990.

CRANSHAW, W. Garden Insects of North America. Princeton, Princeton University Press, 2004.

CREGAN, P. B.; JARVIK, T.; BUSH, A. L.; SHOEMAKER, R. C.; LARK, K. G.; KAHLER, A. L.; KAYA, N.; VANTOAI, T. T.; LOHNES, D. G.; CHUNG, J.; SPECHT, J. E. An integrated genetic linkage map of the soybean genome. Crop Science, v. 39, n., 1464-1490, 1999.

CREST, M.; JACQUET, G.; GOLA, M.; ZERROUK, H.; BENSLIMANE, A.; ROCHAT, H.; MANSUELLE, P.; MARTIN-EAUCLAIRE, M. F. Kaliotoxin, a novel peptide inhibitor of neuronal BK-type Ca2+ -activated $\mathrm{K}+$ channels characterized from Andorctonus mauretanicus mauretanicus venom. Journal of Biological Chemistry, v. 267, n., 1640-1647, 1992.

EHWAETI, M. E.; FARGETTE, M.; PHILLIPS, M. S.; TRUDGILL, D. L. Host status differences and their relevance to damage by Meloidogyne incognita. Nematology, v. 1, n., 421-432, 1999.

EISENBACK, J. D.; TRIANTAPHYLLOU, H. H. Manual of Agricultural Nematology. New York, 1991.

ESCOBAR, C.; BARCALA, M.; PORTILLO, M.; ALMOGUERA, C.; JORDANO, J.; FENOLL, C. Induction of the Hahsp17.7G4 promoter by root-knot nematodes: involvement of heat-shock elements in promoter activity in giant cells. Molecular Plant Microbe Interaction, v. 16, n. 12, 1062-1068, 2003.

FAIRBAIRN, D. J.; CAVALLARO, A. S.; BERNARD, M.; MAHALINGA-IYER, J.; GRAHAM, M. W.; BOTELLA, J. R. Host-delivered RNAi: an effective strategy to silence genes in plant parasitic nematodes. Planta, v. 226, n. 6, 1525-33, 2007.

FANELLI, E.; DI VITO, M.; JONES, J. T.; DE GIORGI, C. Analysis of chitin synthase function in a plant parasitic nematode, Meloidogyne artiellia, using RNAi. Gene, v. 349, n., 87-95, 2005.

FEDERICI, B. A. Insecticidal bacteria: an overwhelming success for invertebrate pathology. Journal of Invertebrate Pathology, v. 89, n., 30-38, 2005.

FINER, J. J.; MCMULLEN, M. D. Transformation of soybean via particle bombardment of embryogenic suspension culture tissue. In Vitro Cell Dev. Biology, v. 27P, n., 175$182,1991$.

FRAGOSO, R. R.; BATISTA, J. A.; NETO, O. B.; GROSSI DE SA, M. F. Isolation and characterization of a cDNA encoding a serine proteinase from the root-knot nematode Meloidogyne incognita. Exp Parasitol, v. 110, n. 2, 123-33, 2005.

FRAGOSO, R. R.; LOURENCO, I. T.; BATISTA, J. A.; OLIVEIRA-NETO, O. B.; SILVA, M. C.; ROCHA, T. L.; COUTINHO, M. V.; GROSSI-DE-SA, M. F. Meloidogyne incognita: molecular cloning and characterization of a cDNA encoding a cathepsin D-like aspartic proteinase. Exp Parasitol, v. 121, n. 2, 115-23, 2009.

FRANCO, O. L.; PEREIRA, J. L.; COSTA, P. H.; ROCHA, T. L.; ALBUQUERQUE, E. V.; GROSSI-DE-SA, M. F.; CARNEIRO, R. M.; CARNEIRO, R. G.; MEHTA, A. Methodological evaluation of 2-DE to study root proteomics during nematode infection in cotton and coffee plants. Prep Biochem Biotechnol, v. 40, n. 2, 152-163, 2010. 
FRANCO, O. L.; SANTOS, R. C. D.; BATISTA, J. A.; MENDES, A. C.; ARAÚJO, M. A. D.; MONNERAT, R. G.; GROSSI-DE-SÁ, M. F.; FREITAS, S. M. D. Effects of black-eyed pea trypsin/chymotrypsin inhibitor on proteolytic activity and on development of Anthonomus grandis. Phytochemistry, v. 63, n. 3, 343-349, 2003.

GATEHOUSE, A. M. R.; SHI, Y.; POWELL, K. S.; BROUGH, C.; HILDER, V. A.; HAMILTON, W. D. O.; NEWELL, C.; MERRYWEATHER, A.; BOULTER, D.; GATEHOUSE, J. A. Approaches to Insect Resistance Using Transgenic Plants. Philosophical Transactions Royal Society London B, v. 342, n., 279-286, 1993.

GILL, S. S.; COWLES, E. A.; PIETRANTONIO, P. V. The mode of action of Bacillus thuringiensis endotoxins. Annual Reviews in Entomology, v. 37, n., 615-636, 1992.

GOMEZ, I.; SANCHEZ, J.; MIRANDA, R.; BRAVO, A.; SOBERON, M. Cadherin-like receptor binding facilitates proteolytic cleavage of helix a-1 in domain I and oligomer pre-pore formation of Bacillus thuringiensis Cry1Ab toxin. FEBS Letters, v. 513, n., 242-246, 2002.

GROSSI-DE-SA, M. F.; GUIMARÃES, L. M.; BATISTA, J. A. N.; VIANA, A. A. B.; FRAGOSO, R. R.; SILVA, M. C. M. Compositions and methods for modifying gene expression using the promoter of ubiquitin conjugating protein coding gene of soybean plants, 2008.

HAQ, S. K.; ATIF, S. M.; KHAN, R. H. Protein proteinase inhibitor genes in combat against insects, pests, and pathogens: natural na engineered phytoprotection. Archives of Biochemistry and Biophysics, v. 431, n., 145-159, 2004.

HARDING, J. A. Heliothis spp.: seasonal occurrence, hosts and host importance in the lower Rio Grande Valley. . Environmental Entomology, v. 5, n., 666-668, 1976.

HERNANDEZ-GARCIA, C. M.; MARTINELLI, A. P.; BOUCHARD, R. A.; FINER, J. J. A soybean (Glycine max) polyubiquitin promoter gives strong constitutive expression in transgenic soybean. Plant Cell Rep, v. 28, n. 5, 837-49, 2009.

HILDER, V. A.; GATEHOUSE, A. M. R.; SHEERMAN, S. E.; BARKER, R. F.; BOULTER, D. A novel mechanism of insect resistance engineered in tobacco. Nature, v. 300, n., 160-163, 1987.

HUANG, G.; ALLEN, R.; DAVIS, E. L.; BAUM, T. J.; HUSSEY, R. S. Engineering broad rootknot resistance in transgenic plants by RNAi silencing of a conserved and essential root-knot nematode parasitism gene. Proceedings Natl Acad Sci U S A, v. 103, n. 39, 14302-6, 2006.

HUNTER, C. P. Gene silencing: shrinking the black box of RNAi. Curr Biol, v. 10, n. 4, R13740, 2000.

IBRAHIM, H. M. M.; ALKHAROUF, N. W.; MEYER, S. L. F.; ALY, M. A. M.; GAMAL ELDIN, A. E. K. Y.; HUSSEIN, E. H. A.; MATTHERWS, B. F. Post-transcriptional gene silencing of root-knot nematode in transformed soybean roots. Experimental Parasitology, n., 2010.

ICHINOHE, M. Current research on the major nematode problems in Japan Journal of Nematology, v. 20, n., 184-190 1988.

ITHAL, N.; RECKNOR, J.; NETTLETON, D.; HEARNE, L.; MAIER, T.; BAUM, T. J.; MITCHUM, M. G. Parallel genome-wide expression profiling of host and pathogen during soybean cyst nematode infection of soybean. Molecular Plant-Microbe Interaction, v. 20, n. 3, 293-305, 2007a.

ITHAL, N.; RECKNOR, J.; NETTLETON, D.; MAIER, T.; BAUM, T. J.; MITCHUM, M. G. Developmental transcript profiling of cyst nematode feeding cells in soybean roots. Molecular Plant-Microbe Interaction, v. 20, n. 5, 510-525, 2007b. 
ITOH, H.; MATSUOKA, M.; STEBER, C. M. A role for the ubiquitin-26S-proteasome pathway in gibberellin signaling. Trends in Plant Science, v. 8, n. 10, 492-497, 2003.

JAMES, C. Global Status of Commercialized Biotech/GM Crops: 2009. The International Service for the Acquisition of Agri-biotech Application (ISAAA), v. 41, n., 2009.

KHAN, R.; ALKHAROUF, N.; BEARD, H.; MCDONALD, M.; CHOUIKHA, I.; MEYER, S.; GREFENSTETTE, J.; KNAP, H.; MATTHEWS, B. Microarray analysis of gene expression in soybean roots susceptible to the soybean cyst nematode two days post invasion. Journal of Nematology, v. 36, n., 241-248, 2004.

KHAN, S. A.; ZAFAR, Y.; BRIDDON, R. W.; MALIK, K. A.; MUKHAR, Z. Spider venom toxin protects plants from insect attack. Transgenic Res, v. 15, n., 349-357, 2006.

KIMBER, M. J.; MCKINNEY, S.; MCMASTER, S.; DAY, T. A.; FLEMING, C. C.; MAULE, A. G. flp gene disruption in a parasitic nematode reveals motor dysfunction and unusual neuronal sensitivity to RNA interference. The FASEB Journal, v. 21, n., 1233-1243, 2007.

KLINK, V. P.; ALKHAROUF, N.; MACDONALD, M.; MATTHEWS, B. Laser capture microdissection (LCM) and expression analyses of Glycine max (soybean) syncytium containing root regions formed by the plant pathogen Heterodera glycines (soybean cyst nematode). Plant Molecular Biology, v. 59, n. 6, 965-979, 2005.

KLINK, V. P.; KIM, K. H.; MARTINS, V.; MACDONALD, M. H.; BEARD, H. S.; ALKHAROUF, N. W.; LEE, S. K.; PARK, S. C.; MATTHEWS, B. F. A correlation between host-mediated expression of parasite genes as tandem inverted repeats and abrogation of development of female Heterodera glycines cyst formation during infection of Glycine max. Planta, v. 230, n. 1, 53-71, 2009.

KNOWLES, B. H. Mechanism of action of Bacillus thuringiensis insecticidal d-endotoxins. Advances in Insect Physiology, v. 24, n., 275-308, 1994.

KOENNING, S. R.; OVERSTREET, C.; NOLING, J. W.; DONALD, P. A.; BECKER, J. O.; FORTNUM, B. A. Survey of crop losses in response to phytoparasitic nematodes in the United States for 1994. J Nematol, v. 31, n. 4S, 587-618, 1999.

KUWABARA, P. E.; COULSON, A. RNAi--prospects for a general technique for determining gene function. Parasitol Today, v. 16, n. 8, 347-9, 2000.

LARA, P.; ORTEGO, F.; GONZÁLEZ-HIDALGO, E.; CASTAÑERA, P.; CARBONERO, P.; DÍAZ, I. Adaptation of Spodoptera exígua (Lepidoptera: Noctuidae) to barley trypsin inhibitor BTI-CMe expressed in transgenic tobacco. Transgenic Res, v. 9, n., 169-178, 2000.

LILLEY, C. J.; BAKHETIA, M.; CHARLTON, W. L.; URWIN, P. E. Recent progress in the development of RNA interference for plant parasitic nematodes. MOLECULAR PLANT PATHOLOGY, v. 8, n. 5, 701-711, 2007.

LILlEY, C. J.; DEVlIN, P.; URWIN, P. E.; ATKINSON, H. J. Parasitic nematodes, proteinases and transgenic plants. Parasitol Today, v. 15, n. 10, 414-7, 1999a.

LILlEY, C. J.; GOODCHILD, S. A.; ATKINSON, H. J.; URWIN, P. E. Cloning and characterisation of a Heterodera glycines aminopeptidase cDNA. Int J Parasitol, v. 35, n. 14, 1577-85, 2005.

LILLEY, C. J.; URWIN, P. E.; ATKINSON, H. J. Characterization of plant nematode genes: identifying targets for a transgenic defence. Parasitology, v. 118 Suppl, n., S63-72, 1999b. 
LILLEY, C. J.; URWIN, P. E.; ATKINSON, H. J.; MCPHERSON, M. J. Characterization of cDNAs encoding serine proteinases from the soybean cyst nematode Heterodera glycines. Mol Biochem Parasitol, v. 89, n. 2, 195-207, 1997.

LILLEY, C. J.; URWIN, P. E.; MCPHERSON, M. J.; ATKINSON, H. J. Characterization of intestinally active proteinases of cyst-nematodes. Parasitology, v. 113 ( Pt 4), n., 41524, 1996.

LIMA, M. D. D.; FIGUEIREDO, S. G.; PIMENTA, A. M. C.; SANTOS, D. M.; BORGES, M. H.; CORDEIRO, M. N.; RICHARDSON, M.; OLIVEIRA, L. C.; STANKIEWICZ, M.; PELHATE, M. Peptides of arachnid venoms with insecticidal activity targeting sodium channels. Comparative Biochemistry and Physiology, Part C, v. 146, n., 264279, 2007.

LU, J.; SIVAMANI, E.; AZHAKANANDAM, K.; SAMADDER, P.; LI, X.; QU, R. Gene expression enhancement mediated by the 5' UTR intron of the rice rubi3 gene varied remarkably among tissues in transgenic rice plants. Mol Genet Genomics, v. 279, n. 6, 563-572, 2008.

LUSTER, D. G.; MCMAHON, M. B.; CARTER, M. L.; FORTIS, L. L.; NUÑEZ, A. Proteomic analysis of germinating urediniospores of Phakopsora pachyrhizi, causal agent of Asian soybean rust. Proteomics, v. v., n. i., epub ahead to print, 2010.

LYSON, T. A. Advanced agricultural biotechnologies and sustainable agriculture. Trends Biotechnol, v. 20, n., 193-196, 2002.

MACEDO, M. L. R.; FREIRE, M. G. M.; CABRINI, E. C.; TOYAMA, M. H.; NOVELLO, J. C.; MARANGONI, S. A trypsin inhibitor from Peltophorum dubium seeds active against pest proteases and its effect on the survival of Anagasta kuehniella (Lepidoptera: Pyralidae). Biochimia et BIophysica Acta, v. 162, n. 2, 170-182, 2003.

MALVICK, D. (2007, 10/08/2010). "Soybean Seed and Seedling Diseases." from http://www.extension.umn.edu/cropdiseases/soybean/soybeandisease.html.

MARRA, B. M.; SOUZA, D. S.; AGUIAR, J. N.; FIRMINO, A. A.; SARTO, R. P.; SILVA, F. B.; ALMEIDA, C. D.; CARES, J. E.; CONTINHO, M. V.; MARTINS-DE-SA, C.; FRANCO, O. L.; GROSSI-DE-SA, M. F. Protective effects of a cysteine proteinase propeptide expressed in transgenic soybean roots. Peptides, v. 30, n. 5, 825-31, 2009.

MCCABE, D.; CHRISTOU, P. Direct DNA transfer using electric discharge particle acceleration (ACCELL technology). Plant Cell Tissue Org. Culture, v. 33, n. 3, 227236, 1993.

MCPHERSON, R. M.; MACRAE, T. C. Evaluation of transgenic soybean exhibiting high expression of a synthetic Bacillus thuringiensis cry1A transgene for suppressing lepidopteran population densities and crop injury. J Econ Entomol, v. 102, n. 4, 1640-8, 2009.

MEDEIROS, L. N. D.; ANGELI, R.; SARZEDAS, C. G.; BARRETO-BERGTER, E.; VALENTE, A. P.; KURTENBACH, E.; ALMEIDA, F. C. Backbone dynamics of the antifungal Psd1 pea defensin and its correlation with membrane interaction by NMR spectroscopy. Biochimica et Biophysica Acta, v. 1798, n. 2, 105-113, 2010.

MEHTA, A.; BRASILEIRO, A. C.; SOUZA, D. S.; ROMANO, E.; CAMPOS, M. A.; GROSSIDE-SA, M. F.; SILVA, M. S.; FRANCO, O. L.; FRAGOSO, R. R.; BEVITORI, R.; ROCHA, T. L. Plant-pathogen interactions: what is proteomics telling us? FEBS J, v. 275, n. 15, 3731-46, 2008.

MICHAUD, D.; CANTIN, L.; BONADE-BOTTINO, M.; JOUANIN, L.; VRAIN, T. C. Identification of stable plant cystatin/nematode proteinase complexes using mildly 
denaturing gelatin/polyacrylamide gel electrophoresis. Electrophoresis, v. 17, n. 8, 1373-9, 1996.

MICKEL, C. E.; STANDISH, J. Susceptibility of processed soy flour and soy grits in storage to attack by Tribolium castaneum. University of Minnesota Agric. Exp. Stn. Tech. Bull, v. 178, n., 1-20, 1947.

MOON, J.; PARRY, G.; ESTELLE, M. The ubiquitin-proteasome pathway and plant development. Plant Cell, v. 16, n. 12, 3181-3195, 2004.

MUKHOPADHYAY, D.; RIEZMAN, H. Proteasome-independent functions of ubiquitin in endocytosis and signaling. Science, v. 315, n. 5809, 201-205, 2007.

MULLER, J. The economic importance of Heterodera schachtii in Europe. Helminthologia, v. 36, n., 205-213, 1999.

MURATANI, M.; TANSEY, W. P. How the ubiquitin-proteasome system controls transcription. Nat Rev Mol Cell Biol, v. 4, n., 192-201, 2003.

MUSEUM, T. N. H. (2007, 28/10/2005). "Butterflies and Moths of the World: Generic Names and their Type-species." Retrieved 09/09/2010, 2010, from http://www.nhm.ac.uk/.

NAKAGAWA, Y.; LEE, Y. M.; LEHMBERG, E.; HERRMANN, R.; MOSKOWITZ, H.; JONES, A. D.; HAMMOCK, B. D. Anti-insect toxin 5 (AaIT5) from A. autralis. European Journal of Biochemistry, v. 246, n., 496-501, 1997.

NEVEU, C.; ABAD, P.; CASTAGNONE-SERENO, P. Molecular cloning and characterization of an intestinal cathepsin L protease from the plant-parasitic nematode Meloidogyne incognita. Physiol. Mol. Plant Pathol., v. 63, n. 3, 159-165, 2003.

ODELL, J. T.; NAGY, F.; CHUA, N. H. Identification of DNA sequences required for activity of the cauliflower mosaic virus 35S promoter. Nature, v. 313, n. 6005, 810-812, 1985.

OLLI, S.; KIRTI, P. B. Cloning, characterization and antifungal activity of defensin Tfgd1 from Trigonella foenum-graecum L. Journal of Biochemistry and Molecular Biology, v. 39, n. 3, 278-283, 2006.

OPPERMAN, C. H.; TAYLOR, C. G.; CONLING, M. A. Root-knot nematode--directed expression of a plant root--specific gene. Science, v. 263, n. 5144, 221-223, 1994.

PARROTT, W. A.; AL, J. N.; ADANG, M. J.; BAILEY, M. A.; BOERMA, H. R.; STEWART, C. N. J. Recovery and evaluation of soybean (Glycine max Merr.) plants transgenic for a Bacillus thuringiensis var. Kurstaki insecticidal gene. In Vitro Cell Dev Biology, v. 30P, n., 114-149, 1994.

PATEL, N.; HAMAMOUCH, N.; LI, C.; HEWEZI, T.; HUSSEY, R. S.; BAUM, T. J.; MITCHUM, M. G.; DAVIS, E. L. A nematode effector protein similar to annexins in host plants. Journal of Experimental Botany, v. 61, n., 235-248, 2010.

PEREMARTI, A.; TWYMAN, R. M.; GÓMEZ-GALERA, S.; NAQVI, S.; FARRÉ, G.; SABALZA, M.; MIRALPEIX, B.; DASHEVSKAYA, S.; YUAN, D.; RAMESSAR, K.; CHRISTOU, P.; ZHU, C.; BASSIE, L.; CAPELL, T. Promoter diversity in multigene transformation. Plant Mol Biol, v. 73, n., 363-378, 2010.

PHAM TRUNG, N.; FITCHES, E.; GATEHOUSE, J. A. A fusion protein containing a lepidopteran-specific toxin from the South Indian red scorpion (Mesobuthus tumulus) and snowdrop lectin show oral toxicity to target insect. BMC Biotechnology, v. 16, n., 6-18, 2006.

PLESSE, B.; CRIQUI, M. C.; DURR, A.; PARMENTIER, Y.; FLECK, J.; GENSCHICK, P. Effects of the polyubituitin gene Ubi.U4 leader intron and first ubiquitin monomer on reporter gene expression in Nicotiana tabacum. Plant Molecular Biology, v. 45, n., 655-667, 2001. 
POTRYKUS, I.; AMMAN, K.; ARBER, W.; VON BRAUN, J.; SWAMINATHAN, M. S.; FEDOROFF, N.; COMINELLI, E.; TONELLI, C.; BEYER, P.; MORANDINI, P.; McGLOUGHLIN, M. N.; FLAVEL, R.; GRESSEL, J.; RAVEN, P. H.; CHASSY, B. M.; PARROTT, W.; QAIM, M.; ANDERSON, K.; ZEIGLER, R. S.; MOHANTY, S.; KRATTIGER, A.; WEALE, A.; BURACHIK, M.; SKRYABIN, K.; MARTIN, M. A.; PAARLBERG, R.; HERRING, R. J.; KERSHEN, D. L.; MILLE, H.I.; APEL, A.; VAN MONTAGU, M. Transgenic plants for food security in the context of development - proceedings of a study week of the Pontifical Academy of Sciences. New Biotechnology, v.27, n.5, 445-718, 2010.

POTENZA, C.; ALEMAN, L.; SENGUPTA-GOPALAN, C. Targeting transgene expression in research, agricultural, and environmental applications: promoters used in plant transformation. In Vitro Cell Dev Biology, v. 40, n. 1-22, 2004.

PURDY, L. H. Sclerotinia sclerotiorum: history, diseases and symptomatology, host range, geographic distribution, and impact. Phytopathology, v. 69, n., 875-880, 1979.

QUISTAD, G. B.; SKINNER, W. S. Isolation and sequencing of insecticidal peptides from the primitive hunting spider, Plectreurys tristis (Simon). Journal of Biological Chemistry, v. 269, n. 15, 11098-11101, 1994.

RAJAMOHAN, F.; LEE, M. K.; DEAN, D. H. Bacillus thuringiensis insecticidal proteins: Molecular mode of action. Prog. Nucleic Acid Research, v. 60, n., 1-27, 1998.

RECTOR, B. G.; ALL, J. N.; PARROTT, W. A.; BOERMA, H. R. Quantitative trait loci for antibiosis resistance to corn earworm in soybean. Crop Science, v. 40, n., 233-238, 2000.

ROCHAT, H.; BERNARD, P.; COURAUD, F. Scorpion toxins: chemistry and mode of action. Advanced Cytopharmacology, n., 325-334, 1979.

ROWE, G. E.; MARGARITIS, A. Bioprocess design and economic analysis for the commercial production of environmentally friendly bioinsecticides from Bacillus thuringiensis HD-1 kurstaki. Biotechnological Bioengineering, v. 86, n. 4, 377-388, 2004.

SASSER, J. N. Root-knot nematodes: a global menace to crop production. Plant Disease, v. 64, n., 36-41, 1980.

SASSER, J. N.; EISENBACK, J. D.; CARTER, C. C. The international Meloidogyne project - its goals and achievements. Annual Review of Phytopathology, v. 21, n., 271-288, 1983.

SATO, S.; NEWELL, C.; KOLACZ, K.; TREDO, L.; FINER, J.; HINCHEE, M. Stable transformation via particle bombardment in two different soybean transformation systems. Plant Cell Rep, v. 12, n., 408-413, 1993.

SELS, J.; SIJN, E.; DELAURE, L.; AERTS, A. M.; PROOST, P.; CAMMUE, B. P. A.; BOLLE, M. F. C. Use of a PTGS-MAR expression system for efficient in planta production of bioactive Arabidopsis thaliana plant defensins. Transgenic Research, v. 16, n., 531$538,2007$.

SHARP, P. A. RNAi and double-strand RNA. Genes Dev, v. 13, n. 2, 139-41, 1999.

SHINGLES, J.; LILLEY, C. J.; ATKINSON, H. J.; URWIN, P. E. Meloidogyne incognita: molecular and biochemical characterisation of a cathepsin L cysteine proteinase and the effect on parasitism following RNAi. Experimental Parasitology, v. 115, n. 2, 114-120, 2007.

SILVA, F. B.; BATISTA, J. A.; MARRA, B. M.; FRAGOSO, R. R.; MONTEIRO, A. C.; FIGUEIRA, E. L.; GROSSI-DE-SA, M. F. Pro domain peptide of HGCP-Iv cysteine proteinase inhibits nematode cysteine proteinases. Genet Mol Res, v. 3, n. 3, 342-55, 2004. 
STEEVES, R. M.; TODD, T. C.; ESSIG, J. S.; TRICK, H. N. Transgenic soybeans expressing siRNAs specific to a major sperm protein gene suppress Heterodera glycines reproduction. Functional Plant Biology, v. 33, n., 991-999, 2006.

STEWART, C. N., JR.; ADANG, M. J.; ALL, J. N.; BOERMA, H. R.; CARDINEAU, G.; TUCKER, D.; PARROTT, W. A. Genetic transformation, recovery, and characterization of fertile soybean transgenic for a synthetic Bacillus thuringiensis cryIAc gene. Plant Physiol, v. 112, n. 1, 121-9, 1996.

STEWART, L. M.; HIRST, M.; LOEZ, F. M.; MERRYWATHER, A. T.; CAYLEY, P. J.; POSSEE, R. D. Construction of an improved baculovirus insecticide containing an insect-specific toxin gene. Nature, v. 352, n., 85-88, 1991.

STIRLING, G. R.; STANTON, J. M.; MARSHALL, J. W. The importance of plant-parasitic nematodes to Australian and New Zealand agriculture. Australasian Plant Pathology, v. 21, n., 104-115, 1992.

SWAN, L. A.; PAPP, C. S. The Common Insects of North America. New York, Harper \& Row Publishers, 1972.

THOMMA, B. P. H. J.; CAMMUE, E. B. P. A.; THESVISSEN, K. Plant defensins. Planta, v. 216, n., 193-202, 2002.

TOWNSEND, J. A.; THOMAS, L. A. An improved method of Agrobacterium-mediated transformation of cultured soybean cells, 1993.

TRUDGILL, D. L.; BLOK, V. C. Apomictic, polyphagous root-knot nematodes: exceptionally successful and damaging biotrophic root pathogens. Annual Review of Phytopathology, v. 39, n., 53-77, 2001.

URWIN, P. E.; LILLEY, C. J.; ATKINSON, H. J. Ingestion of double-stranded RNA by preparasitic juvenile cyst nematodes leads to RNA interference. Molecular PlantMicrobe Interaction, v. 15, n. 8, 747-752, 2002.

URWIN, P. E.; LILLEY, C. J.; MCPHERSON, M. J.; ATKINSON, H. J. Characterization of two cDNAs encoding cysteine proteinases from the soybean cyst nematode Heterodera glycines. Parasitology, v. 114 ( Pt 6), n., 605-13, 1997a.

URWIN, P. E.; LILLEY, C. J.; MCPHERSON, M. J.; ATKINSON, H. J. Resistance to both cyst and root-knot nematodes conferred by transgenic Arabidopsis expressing a modified plant cystatin. Plant J, v. 12, n. 2, 455-61, $1997 \mathrm{~b}$.

URWIN, P. E.; MCPHERSON, M. J.; ATKINSON, H. J. Enhanced transgenic plant resistance to nematodes by dual proteinase inhibitor constructs. Planta, v. 204, n. 4, 472-9, 1998.

URWIN, P. E.; MOLLER, S. G.; LILlEY, C. J.; MCPHERSON, M. J.; ATKINSON, H. J. Continual green-fluorescent protein monitoring of cauliflower mosaic virus $35 \mathrm{~S}$ promoter activity in nematode-induced feeding cells in Arabidopsis thaliana. Mol Plant Microbe Interact, v. 10, n. 3, 394-400, 1997c.

VENTER, M. Synthetic promoters: genetic control through cis engineering. Trends in Plant Science, v. 12, n. 3, 118-124, 2007.

WALKER, D. R.; ALL, J. N.; MCPHERSON, R. M.; BOERMA, H. R.; PARROTT, W. A. Field evaluation of soybean engineered with a synthetic cry1Ac transgene for resistance to corn earworm, soybean looper, velvetbean caterpillar (Lepidoptera: Noctuidae), and lesser cornstalk borer (Lepidoptera: Pyralidae). J Econ Entomol, v. 93, n. 3, 61322, 2000.

WALKER, D. R.; NARVEL, J. M.; BOERMA, H. R.; ALL, J. N.; PARROTT, W. A. A QTL that enhances and broadens Bt insect resistance in soybean. Theor Appl Genet, v. 109, n. 5, 1051-7, 2004. 
WANG, H. X.; NG, T. B. Isolation and characterization of an antifungal peptide with antiproliferative activity from seeds of Phaseolus vulgaris cv. 'Spotted Bean'. Applied Microbiological Biotechnology, v. 74, n. 1, 125-130, 2007.

WANG, J.; OARD, J. H. Rice ubiquitin promoters: deletion analysis and potential usefulness in plant transformation systems. Plant Cell Rep, v. 22, n., 129-134, 2003.

WEERDEN, N. L. V. D.; ANDERSON, M. A. The plant defensin, NaD1, enters the cytoplasm of Fusarium oxysporum hyphae. Journal of Biological Chemistry, v. 283, n. 21, 14445-14452, 2008.

WESSEL, V. L.; TOM, R.; ANTOINETTE, B.; LINUS, V. P.; ALEXANDER, V. K. Characterization of position induced spatial and temporal regulation of transgene promoter activity in plants. Journal of Experimental Botany, v. 52, n., 949-959, 2001.

WILHITE, S. E.; ELDEN, T. C.; BRZIN, J.; SMIGOCKI, A. C. Inhibition of cysteine and aspartyl proteinases in the alfalfa weevil midgut with biochemical and plantderived proteinase inhibitors. Insect Biochem Mol Biol, v. 30, n. 12, 1181-8, 2000.

WRATHER, J. A.; ANDERSON, T. R.; ARSYAD, D. M.; TAN, Y.; PLOPER, L. D. Soybean disease loss estimates for the top ten soybean-producing countries in 1998. Journal of Plant Pathology, v. 23, n., 115-121, 2001.

WRATHER, J. A.; ANDERSON, T. R.; ARZSAD, D. M.; GAI, J.; PLOPER, L. D.; PORTAPUGLIA, A.; RAM, H. H.; YORINORI, Y. T. Soybean disease loss estimates for the top 10 soybean-producing countries in 1995. Plant Disease, v. 81, n., 107-110, 1997.

WUDAYAGIRI, R.; INCEOGLU, B.; HERRMANN, R.; DERBEL, M.; CHOUDARY, P. V.; HAMMOCK, B. D. Isolation and characterization of a novel lepidopteran-selective toxin from the venon of South Indian red scorpion, Mesobuthus tumulus. BMC Biochemistry, v. 2, n., 16, 2001.

WYLLIE, T. D; WILLIAMS, L. F. The effects of temperature and leaf age on the development of lesions caused by peronospora manshurica on soybeans. Phytopathology, v. 55, n., 166-170, 1965.

YADAV, B. C.; VELUTHAMBI, K.; SUBRAMANIAM, K. Host-generated double stranded RNA induces RNAi in plant-parasitic nematodes and protects the host from infection. Molecular Biochemistry Parasitolology, v. 148, n. 2, 219-22, 2006.

ZENG, L. R.; VEGA-SANCHEZ, M. E.; ZHU, T.; WANG, G. L. Ubiquitination-mediated protein degradation and modification: An emerging theme in plant-microbe interactions. Cell Res, v. 16, n. 413-426, 2006.

ZHANG, X. H.; ZHONG, W. Q.; WIDHOLM, J. M. Expression of a fungal cyanamide hydratase in transgenic soybean detoxifies cyanamide in tissue culture and in planta to provide cyanamide resistance. J Plant Physiol, v. 162, n. 9, 1064-73, 2005.

ZHOU, J.-Y.; LIAO, H.; ZHANG, N.-H.; TANG, L.; XU, Y.; CHEN, F. Identification of a Kunitz inhibitor from Albizzia kalkora and its inhibitory effect against pest midgut proteases. Biotechnological Letters, v. 30, n., 1495-1499, 2008.

ZHU, S.; WALKER, D. R.; BOERMA, H. R.; ALL, J. N.; PARROTT, W. A. Effects of defoliating insect resistance QTLs and a cry1Ac transgene in soybean near-isogenic lines. Theor Appl Genet, v. 116, n. 4, 455-63, 2008.

ZLOTKIN, E.; EITAN, M.; BINDOKAS, V. P.; ADAMS, M. E.; MOYER, M.; BURKART, W.; FOWLER, E. Functional duality and structural uniqueness of depressant insectselective neurotoxins. European Journal of Biochemistry, v. 267, n., 1640-1647, 1991. 


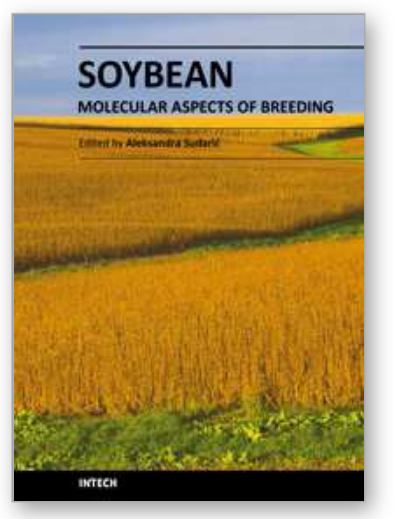

\author{
Soybean - Molecular Aspects of Breeding \\ Edited by Dr. Aleksandra Sudaric
}

ISBN 978-953-307-240-1

Hard cover, 514 pages

Publisher InTech

Published online 11, April, 2011

Published in print edition April, 2011

The book Soybean: Molecular Aspects of Breeding focuses on recent progress in our understanding of the genetics and molecular biology of soybean and provides a broad review of the subject, from genome diversity to transformation and integration of desired genes using current technologies. This book is divided into four parts (Molecular Biology and Biotechnology, Breeding for Abiotic Stress, Breeding for Biotic Stress, Recent Technology) and contains 22 chapters.

\title{
How to reference
}

In order to correctly reference this scholarly work, feel free to copy and paste the following:

Maria Fatima Grossi-de-Sa, Patrícia B. Pelegrini and Rodrigo R. Fragoso (2011). Genetically Modified Soybean for Insect-Pests and Disease Control, Soybean - Molecular Aspects of Breeding, Dr. Aleksandra Sudaric (Ed.), ISBN: 978-953-307-240-1, InTech, Available from: http://www.intechopen.com/books/soybeanmolecular-aspects-of-breeding/genetically-modified-soybean-for-insect-pests-and-disease-control

\section{INTECH}

open science | open minds

\author{
InTech Europe \\ University Campus STeP Ri \\ Slavka Krautzeka 83/A \\ 51000 Rijeka, Croatia \\ Phone: +385 (51) 770447 \\ Fax: +385 (51) 686166 \\ www.intechopen.com
}

\author{
InTech China \\ Unit 405, Office Block, Hotel Equatorial Shanghai \\ No.65, Yan An Road (West), Shanghai, 200040, China \\ 中国上海市延安西路65号上海国际贵都大饭店办公楼 405 单元 \\ Phone: +86-21-62489820 \\ Fax: $+86-21-62489821$
}


(C) 2011 The Author(s). Licensee IntechOpen. This chapter is distributed under the terms of the Creative Commons Attribution-NonCommercialShareAlike-3.0 License, which permits use, distribution and reproduction for non-commercial purposes, provided the original is properly cited and derivative works building on this content are distributed under the same license. 